\title{
TV 技術を利用したモアレトポグラフィ*
}

\author{
浜崎祐司** 丹羽 登***
}

\section{1. 緒言}

モアレ法を用いて三次元物体の等高線画像を得る方法 こして, 征来格子照射法や格子投影法が開発されてい る12). 格子投影法の場合, 投影側格子, 観察例格子と して，ガラス面に黑い線をストライプ状に引いたものな ぞぶ使用されてきた。このため，格子のピッチや投影， 観察両格子の位置関倸を变元るためには，格子を取り換 えたり機械的に移動・回転する手段がとら机てきた。

そこで，電気的化制御可能な観察側格子を作成卞るた 方にこれまでモアレ縞観察用モニタとして使用される に過ぎなかった TV 系定積㥛的に応用主る方法苍考案 した。亦なわち，ITVで観察された変形格子画像を画像 蓄積面に記憶し, 後処理として蓄積面上で観察側格子を 電気的に作成しモアレ縞を発生させる方法である。

本方式に上机壮，TV 系を変形格子画像観察用モニタ として使用方る結果得られる特徽以外に, 電気的に制御 可能な観察側格子を用いて，以下のことを容易に実現で きる.

(1) 等高線間隔を可変汒できる.

(2) 物体の凹凸を判定できる.

(3) 斜的方向に切断できる (基潐面の変化).

(4) 変形格子画像を記録しておけ汿，後処理でモアレ 縞を発生できる。

\section{2. 装置の構成}

図 1 亿本装置の構成老示与。

ここでSCM とは, Hughes Aircraft Company 製の 走查恋換記憶装置 (scan conversion memory 装置) 3 ) で 方り，次の目的で使用している.

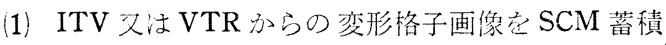
面上汇記憶严る。

(2) SCMのXY 選択消去モードを利用して, 蓄穔さ れた変形格子画像から観察側格子に相当与る領域老

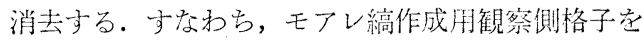
電気的作る.

* 原稿受付 昭和 51 年 4 月 9 日. 昭和 51 年度精機学会春 季大会学術講演会 (昭和 51 年 4 月 4 日) 亿て発表.

** 学生会員 東京大学宇值航空研究所 (東京都目黑区駒場 4-6-1)

*** 正会 員 東京大学宇活航空研究所
（3）（2）の消去の速度，回数を変えることにより消去の 度合（観察側格子のコントラスト）を調整する。

図 2 红 X 選択消去モード洔汇必要な信号発生器, 寸 なわち, X 偏向信号発生器 (X def), Y 偏向信号発生器 (Y def), XY アンブランキング信号発生器 (XY-UB)の ブロック図を示す， SCM 注，XY 選択消去モードで動作 する場合，XY-UB 信号が論理レベル 1 の時に, X def, Y def で決定される蓄積面上の部分を消去する。本実験 で核縦の格子を作るために, X def は D-A 变換器出力の

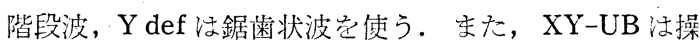
作盤の 8 個のスイッチの on (1), off $(0)$ で決定されるパ ターンを 1 周期とする格子を作るために, データセレク

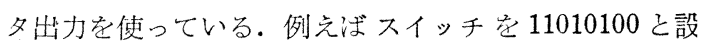
定す机ば，XY-UB 信号は論理レベルで 11010100110101 $0011 \cdots \cdots .$. のパルス列になり，モ二タ上で観察すると00， 部分が透明，1の部分が不透明な格子が作ら机る。

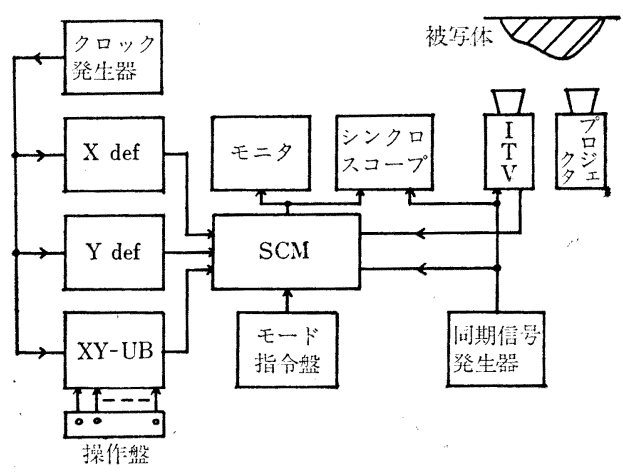

図 1 装置の構成

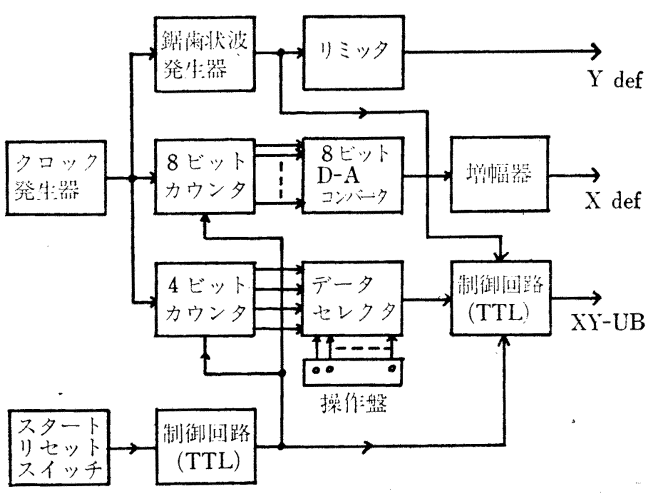

図 2 各信号発生器のブロック図 


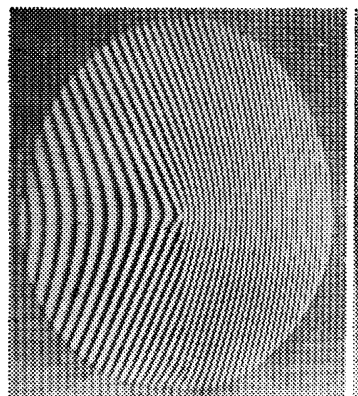

(a) 変形格子

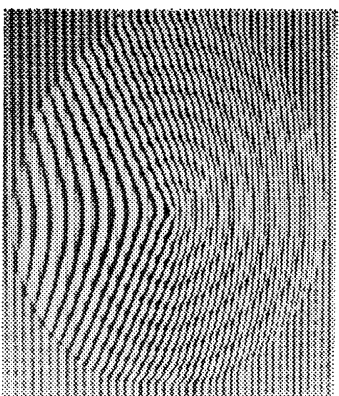

(b) モアレ縞
図 3 モアレ等高線滴

以上の装置て観察側格子芯作る絬果, この格子冲次 の二つの大きな特徴を持っている.

F 1：格子間隔赏可変にできる.

（F1の1）たとえば，スイッチを10101010から 11001100 汇変えると格子のピッチは 2 倍になる.

(F 1 の) $\mathrm{X}$ def 信号の D-A 变換器出力を变光机 ば黑白の比注 1 対 1 ではないが，ピッチは連続的に変 化する格子虹作ることができる。

F 2：格子空シフトすることができる.

スイッチを 11001100 から 10011001 に変え机ば，格 子パターンは $1 / 4$ 周期だけシフトされる。これは，投 影側格子に対する観察側格子の位置を $1 / 4$ 周期だけ平 行移動させたことに対応する。

さて, 図 3 亿本装置によってモアレ等高線縞を得た 様子を示す．（a）は変形格子画像，(b) はモアレ縞で 西る. 被写体注底面の半径 $15 \mathrm{~cm}$, 高さ $20.5 \mathrm{~cm}$ の円 すいで，等高線間隔法約 $2.5 \mathrm{~cm}$ である。これは，乇 アレ縞の深さを表す公式 ${ }^{4)} h_{n}=b^{2} p(n-1) /\{a \cdot l-b p$. $(n-1)\}(a$ : 格子より主点までの距離, $b$ : 主点より物 体の基準点宋での距離， $p_{0}$ : 基準格子のピッチ， $h_{n}$ : $n=1,2, \cdots \cdots$ 点のモアレ縞の間隔, $l$ : 二つの光学系の 主点間距離) に本系の数值 $a=14 \mathrm{~cm}, b=220 \mathrm{~cm}$, $p_{0}=0.04 \mathrm{~cm}, l=60 \mathrm{~cm}$ を代入した時の $h_{5}$ と $h_{4}$ の差， $h_{5}-h_{4}=2.5 \mathrm{~cm}$ によく一致している.

\section{3. 本方式の特徵}

本方式の特徵は，従来カメラで観察，記録していたも のを TV 系に変えたこと，及びTV 系を積極的に応用し て電気的に制御可能な観察側格子を作った点にあるが， その結果として,次のことを実現できることを確かめた。

(1) 等高線間隔を可変にできる.

F 1 の方法で観察側格子のピッチ变光，それに対応 して投影側レンズの倍率をズーム系で変化させることに

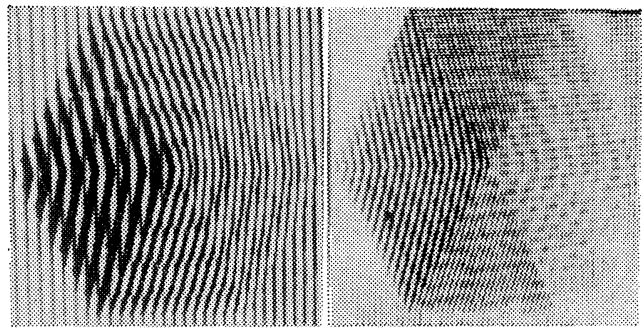

(a)

(b)

被写体は六角すい

図 4 等高線間隔可変 (1)

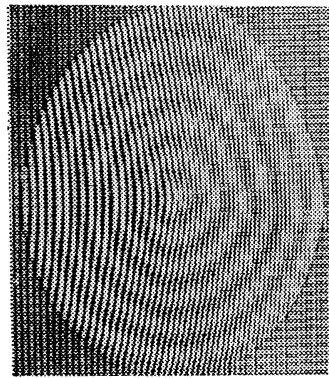

(a)

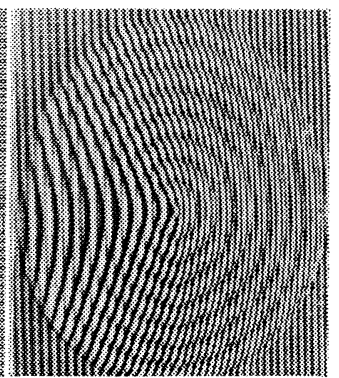

(b)
図 5 等高線間隔可变 $(2)$

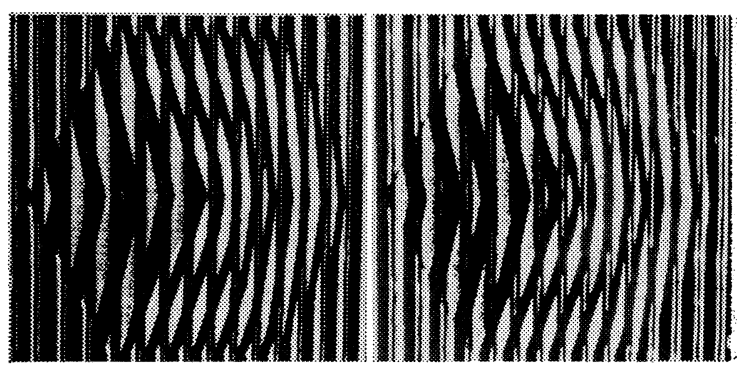

(a) 11001100によるモアレ縞

(b) 10011001によるモアレ縞

被写体は図 4 と同じ 図6凹凹の判定

より等高線間隔を可変にできる。

图 4 に（F1の1）による例を示す，この場合，等高線 間隔は (a)が (b)の 2 倍になっている.

図 5 に (F 1の 2) による例を示す。この場合，等高線 間隔は (a)が (b) の約 1.3 倍になっている.

(2) 物体の山凸を判定できる.

ITVとプロジェクタの位置関係が図 1 のようになって いる場合，F 2 の方法で観察側格子を右 (左)にシフトす れば，モアレ縞のできる等高面の位置は，手前（後方） に移動する，従って，格子をシフトした場合のモアレ縞 の移動方向観察することにより物体の凹凸を判定でき 


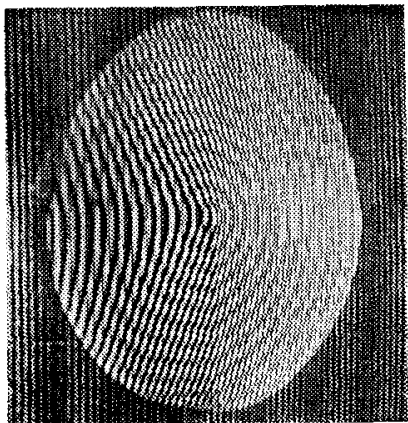

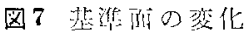

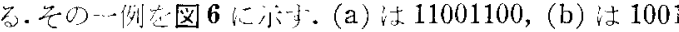

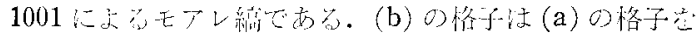

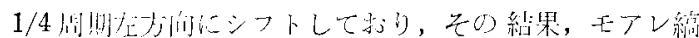

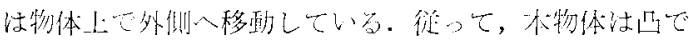

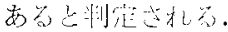

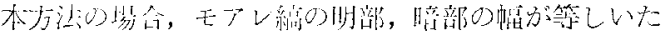

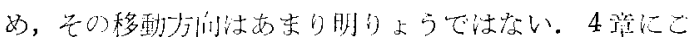

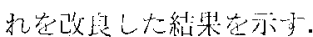

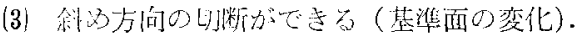

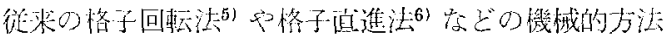

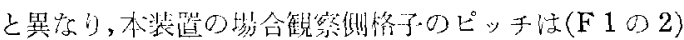
の方法で容易に变化さ垃るこができる。したがって，

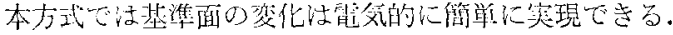

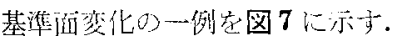

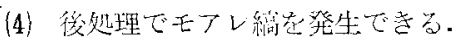

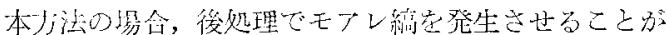

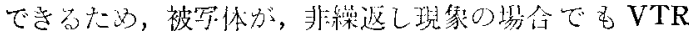

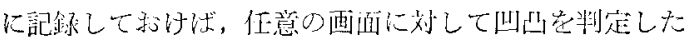
り斜方向の断断の処理安加えることができる。

(5)聂讁観察ができる。

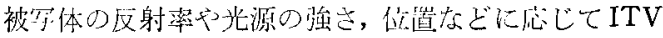
のエントラストメブライトネス等條整することにより変 形格子画像の蚁適歓察が可能である。

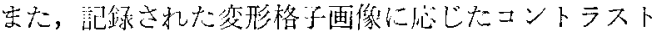

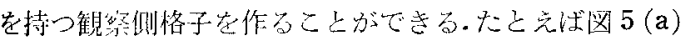
のように，観察側格子は目立たなくてもモてレ縞索生じ さ迄るとかでさる。

(6) ビデオ信望花朋いた画像処理ができる。

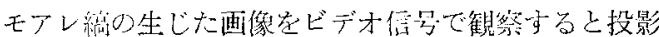
された格子出モナレ絽によって振幅变調されてた形になっ

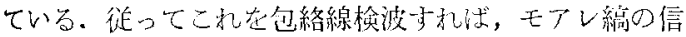

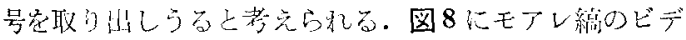

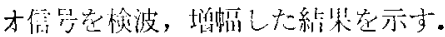

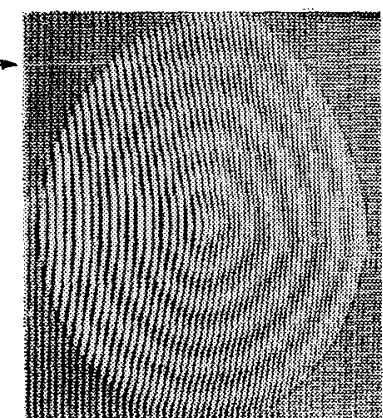

モTレ縞



蚞波导れた信号

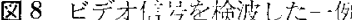

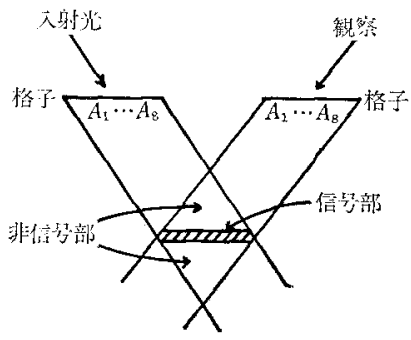

图 9 格子パターンの設塥

\section{4. 明部・暗部の幅が等しくないモアレ縞の作成}

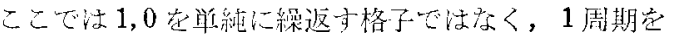

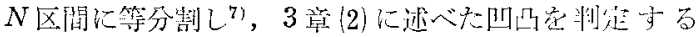

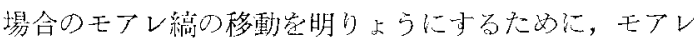
綰の明るい部分の幅か腤い部分に比べて狭くなるよらな 格子パターン在数檤訃算により設計した。

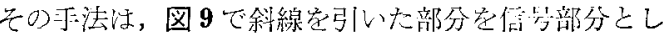

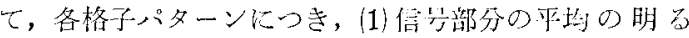

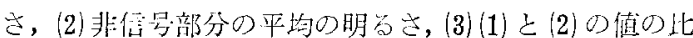

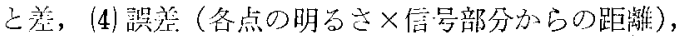

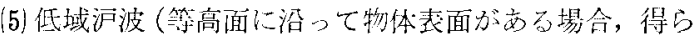
れたモアレ像在 RC 河波器で低域沪波した結夥の染さ方

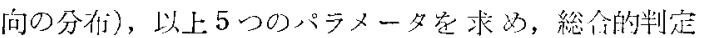
により，最邀格子パーン花選択した。

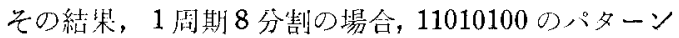

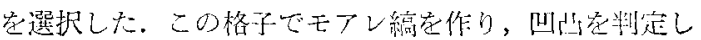

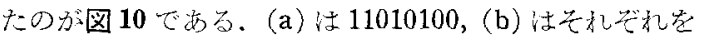
1/8 周期左方间にシフトした 10101001 にるモアレ縞

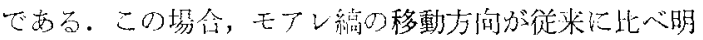
りょうに度るたか，凹凹籼定が容易になる。

\section{5. 結} 論

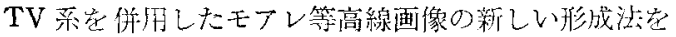




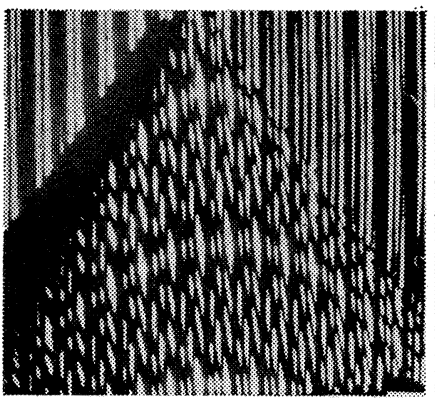

(a) 11010100によるモアレ縞

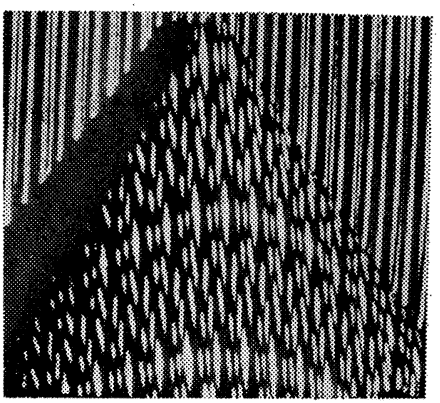

(b) 10101001によるモアレ縞

被写体は円すい

図 10 明暗の幅の異なるモアレ縞による凹凹の判定

考案し装置炎試作した，本装置は，電気的に制御可能な 観察側格子を使う結果として，3 章に述べた特徵を持つ ことが実験的に確かめられた。また 4 章には，明るい部 分の幅が暗い部分の幅に比べて狭くなるようなモアレ縞 を作るために格子パターンを設計し，11010100を選び良 好な結果を得た。

今後改良すべき点としては，格子のピッチをさらに細 かくすること，ビデオ信号でモアレ縞を取り出し処理す

るシステムを作ること，さらには，投影側 格子も何らかの方法で制御できるようにす ることである。

最後に, 本研究に協力さ机た当研究室の 佐下橋市太郎助手，吉田安德技官に深甚の 謝意を表します。

\section{参 考 文 献}

1) H. Takasaki: Moiré Topography, Appl. Opt., 9, 6, (1970) 1467.

2）吉澤 徹，清水茂久：投影法沉よるモ了 レトポロジーとその空用, 昭和 46 年度 精機学会春季大会学術講演会前刷(1971) 245.

3) Hughes Aircraft Company: Sca Conversion Memory Instruction Manual.

4）鈴木正根，鈴木喜義，金谷元德，関 一寿：モアレトポ ロジーによる球面の測定, 昭和 46 年度精機学会春季大 会学術講演会前刷 (1971) 239

5）鈴木正根，鈴木喜義：格子回転汇よる切断面変化法，昭 和 49 年度精機学会秋季大会学術講演会前刷 (1974) 367.

6）吉澤 徹，山階正樹：モアレトポグラフィにお汀る基準 面変化，精密機械，42，3 (1976) 71.

7) R.H. Katyl: Moiré Screen Coded with Pseudorandom Sequence, Appl. Opt., 11, 10 (1972) 2278.
パターン情報処理システム研究の法人化

工業技術院が大型プロジェクトとして開発它すすめて いる「パターン情報処理システム (PIPS)」法各情報認識 パターンのパイロットモデル作成段階に入っているが， 民間の受託 5 社で組織しているパターン情報処理総合シ ステ公研究開発組合（理事長・玉置敬三氏＝東芝会長） は開発が本格段階に入ったのを機に，これ安での任意団 体を改組, 特殊法人「パターン情報処理技術研究組合(仮 称)」として新発足することになった，現在 4 月上旬発 足をメドに準備をす埕めているが，法人化により現在工 技院と各社個別に行われていた情報連絡，委託契約は同 法人足一括空口として行われるようになり，よりスムー ズな研究開発体制がとれるようになるものとみられる。

ところで，パターン情報処理システム開発は人問の音 声や交字, 図形, 模様, 物体など生のデー夕觉直接電算 機に入力させるもので, 究極の意味でのコンピュータと 人間の対話を実現するものである。

46 年度からスタートし， 51 年度で各情報パターンの パイロットモデル作成に着手するなど，開発も本格段階 に入った。

\section{報}

これに対応し，50 年 2 月，東芝，日立製作，三菱電 機, 日本電気, 富士通の民間受託 5 社が任意団体「パタ ーン情報処理総合システム研究組合」を設立，5社間の 情報連絡，調整をすすめてきた。

各社の開発テーマは, 東芝が漢字認識, 濃淡図形認識 パターン，富士通が手書き文字認識パターン，三菱電機 が色彩図形認識，日立製作が物体認識の各パターン開発 を担当，研究をす的てきたが，今年度内に各認識パタ ーンのパイロットモデルが完成する.

同時に同プロジェクトの大容量記憶システムの中核と なる5000 グート(単位諭理回路)という超高性能マイク ロプロセサの試作に入るなど，パターン情報処理システ 公開発も本格段階に入った。こうしたことから受託各社 間の連絡, 調整を一層緊密化する必要があることから法 人化することになったものである。

4 月上旬注溌足の予定で，発足後，これ宗で工技院 と 5 社で個別に結えでいた委託契約などを組合を通して 一括することになるため専彷職員を複数名置いて事務局 機構を整備する必要があり, 現在検討定急いでいる。

（服部 敏夫） 


\title{
精密はかり用目盛の精度*
}

\author{
今井秀 孝** 飯塚幸 三**
}

1.は じめに

電子料金ばかりや直示天びんの開発は，質量測定の簡 便化とともに精度向上にも大いに貢献している. 従来, はふりの検査は，はかりとして組立てられた状態で行う ことが多く、壮ね亦るいは目盛など部品単位の性能老調 ベること汸少なかった。精密はかり用の目盛に関して 注，これまで詳細な精度評洒を行った報告はなく，検査 の方法についても個々の目盛の寸法誤差を求める程度で あり, 現状の目盛の精度の把握はなされていないそこ で, 精機学会はかりの精度調查分科会において, 種々の 精密汸引用目盛の精度評価が一つの研究課題として要 求されるに至った。

本研究では, 精密はかり用の目盛線, コード板, スリ ットなどの性能を調べるために, 簡単な測定装置及び測 定方法を考案して, 実験計画法に基づいた測定を行った 上で精度を評価したので，その結果について報告する。

\section{2. 実 験 方 法}

実験に用いた目盛は表 1 亿示卞直線目盛 3 種類と円弧 目盛 1 種類である.スリットI と円弧のコード板の拡大 写真を图 1 亿示す，性能評価のためには, 目盛の全範囲 をいくつかに分離した図 2 の $A$ 間の精度 (これを広範囲 精度と呼ぶことにする) と $A$ 内での個々の目盛 $B$ 間の 精度（これを狭範囲精度と呼ぶ）を明らかにして, 総合 的な精度を求めることが必要である。このほかに因子と しては, 試料 (目盛板, 記号: $M$ ), 測定の反復 $(R)$ 及び 襙返しをとりあげた。

\section{1 直線目盛の場合}

直線目盛の測定には，図３に示すようなレーザ干渉測 長機 (Hewlett Packard 社製) を用いた測定装置を組立 てた. 試料を固定した載物台を動かし, 顕微鏡視野内の 十字線と目盛線あるいはスリットの端を合致させ，その ときの載物台の移動量を載物台上に固定したキューブコ ーナプリズムとレーザ干渉測長機で検出する方法をとっ た。また，実際の測定においては，同一種類の目盛板 3 枚を用意し，目盛全体を三つの広範囲に分離した上で,

* 原稿受付 昭和 51 年 8 月 24 日. 昭和 50 年度精機学会秋 季大会学術講演会 (昭和 50 年 11 月 22 日) にて発表.

** 正会員 計量研究所 (東京都板橋区加賀 1-10-4)
その各範囲内での連続する 5 目盛のみを狭範囲とした。

\section{2 円弧目盛の場合}

円弧目盛の場合, 広範囲精度と狭範囲精度に分けて解 析することは直線目盛のときと同様であるが，測定には 投影機 (倍率 50 倍) を用いてスクリーン上の十字線と各 測定位置を合致させる方法により, 載物台の移動量から 各測定点の $(x, y)$ 座標を求める. 次に図 4 に示すように

表 1 篹験に用いた目盛の種類

\begin{tabular}{|c|c|c|c|c|}
\hline \multicolumn{3}{|c|}{ 目盛の種類 } & $\begin{array}{c}\text { 最小目盛 } \\
(\mu \mathrm{m})\end{array}$ & 材 質 \\
\hline \multirow{5}{*}{ 直線 } & \multicolumn{2}{|c|}{ スケール } & 38 & ガラス \\
\hline & \multirow[t]{2}{*}{ コード板 } & $I$ & 60 & ガラス \\
\hline & & II & 300 & ガラス \\
\hline & \multirow{2}{*}{ スリット } & I & 240 & ステンレ ス鋼 \\
\hline & & II & 240 & リン青銅 \\
\hline \multicolumn{3}{|c|}{ 円泒コード板 } & $6.6^{\prime}$ & ガラス \\
\hline
\end{tabular}

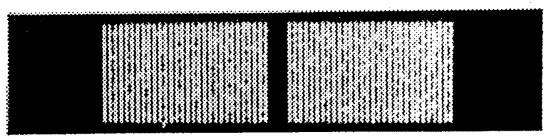

スリットI（ステンレス鋼製，1目 $240 \mu \mathrm{m}$ )

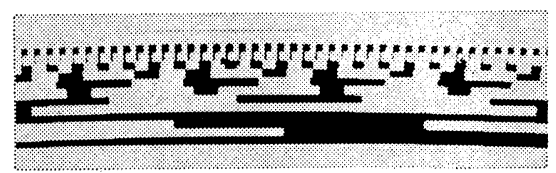

円弧コード板（曲率半径 $212 \mathrm{~mm}$ )

図 1 实験に用いた目盛の拡大写真

$A$ ：公範划精度

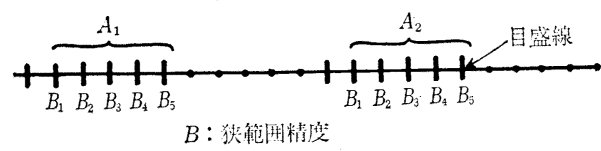

図 2 測定位置の分離方法

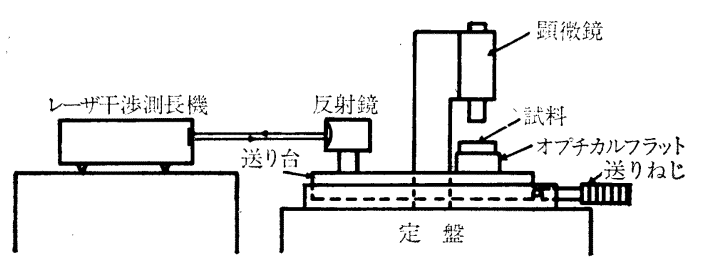

図 3 測定装置の概略 


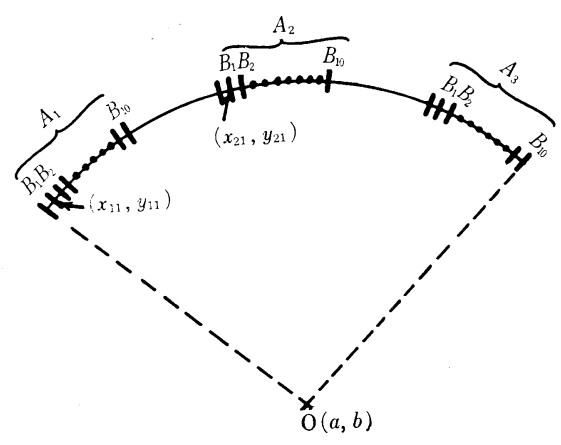

図 4 円孤目盛の測定方注:

全測定点の座標它用い，円の方程式にあて汸的て，最小 二乘法汇よりそ中心位置 $\mathrm{O}(a, b)$ を推定寸れば”，個 個の目盛の角度 $\theta_{i j}(i=1,2,3 ; j=1,2, \cdots \cdots, 10)$ は次式 から計算できる.

$$
\theta_{i j}=\left|\tan ^{-1} \frac{y_{i j+1}-b}{x_{i j+1}-a}-\tan ^{-1} \frac{y_{i j}-b}{x_{i j}-a}\right|
$$

\section{3. 実験結果と考察}

\section{1 直線目盛の場合}

前章で述べた実験計画に基づいて測定を行った結果 を，目盛の種類ごとに分散分析して精度評価を行うこと にした。この場合，狭範囲での等間隔性を調べるため に, 要因 B について注一次回州項とその残差項に分離し て解析した。このようにして要因効果の有意性を検定し た結果を表 2 亿示す. 表 2 には本測定方法の精度を明ら かにするため，標準尺を用いた実駼結果も同時に示して
ある. 有意性を示す要因の数は, スケール，コード板， スリットの順に増えており, コード板及びスリットに関 しては狭範囲における一次回帰からの残差が有意となっ て, 等間隔目盛としては, ずれが大きいことを示してい る.これらの結果を統一的に扱うために, 表 2 の結果を もとにして目盛の精度を次のような分類法によって評価 することにした。

\section{i）広範囲精度}

表 2 にいて，二次誤差より上の要因により精度評価 を行い，有意となる要因がない場合には，二次誤差の誤 差分散の推定值 $\hat{\sigma}_{e_{2}}^{2}$ がその指標となる. 要因 $A$ あるいは $M \times A$ が有意ならば，これらの効果も含めて誤差評価觉 行う必要がある。たとえば，スリットIの場合， $\hat{\sigma}_{A}^{2}=$ $\left(V_{A}-V_{s_{2}}\right) / 60, \hat{\sigma}_{M \times A}^{2}=\left(V_{M \times A}-V_{e_{2}}\right) / 20$ を求的て, 広範 囲精度の $99 \%$ 信頼限界幅注次式のようになる。

$$
\pm\left(F_{\phi_{e 2}}^{1} \times \hat{\sigma}_{e_{2}}^{2}+F_{\phi_{A}}^{1} \times \hat{\sigma}_{A}^{2}+F_{\phi_{M \times A}}^{1} \times \hat{\sigma}_{M \times A}^{2}\right)^{1 / 2}
$$

ここで, $V$ 法不偏分散であり, 添字 $e_{2}$ 等はそ机先机表 2 の要因に対応する。安た, $F_{\phi_{e 2}}^{1}$ 沈白由度 $\left(1, \phi_{e_{2}}\right)$ に対 する $99 \%$ 信頼率の值を $F$ 表から求めたものである.

\section{ii） 狭範囲精度}

狭範囲精度は, 表 2 における $B_{l}$ から $e_{3}$ までの要因効 果により求めら机，広範囲の場合と同様の考元で有意と なる要因がない場合には， $\hat{\sigma}_{e_{3}}^{2}=\left(V_{e_{3}}-V_{e_{4}}\right) / 2$ が狭範囲誤 差の分散の推定值となる. $B_{r}, M \times B_{l}$ 等が有意となる場 合にはこれらの効果も考慮する必要がある。

iii）繰返し測定の精度

$\hat{\sigma}_{e_{4}}^{2}=V_{e_{4}}$ から, $\pm\left(F_{\phi_{e_{4}}}^{1} \times \hat{\sigma}_{e_{4}}^{2} / 2\right)^{1 / 2}$ として, 繰返し数 2 の場合の $99 \%$ 信頼限界が求まる.

表 2 直線目盛についての分散分析結果

（数值は不偏分散を示す. 単位： $\mu \mathrm{m}^{2}$ )

\begin{tabular}{ll|c|c|c|c|c|c|c}
\hline \multicolumn{1}{c}{ 要 } & 因 & 自由度 & 標準尺 & スケール & スード板 I & エード板 II & スリット I & スリット II \\
\hline 反 復 & $R$ & 1 & 0.0056 & 0.3128 & 0.9391 & 2.4379 & 5.0351 & 13.2567 \\
試 料 & $M$ & 2 & 0.0001 & 1.0051 & 1.3483 & 5.3596 & 16.6407 & 58.8007 \\
一次誤差 & $e_{1}$ & 2 & 0.2084 & 1.0822 & 1.1901 & 2.6465 & 15.7407 & 6.7747 \\
広範囲 & $A$ & 2 & 0.0253 & 2.7674 & 20.6569 & $11.3606^{*}$ & $125.5383^{* *}$ & $86.1853^{*}$ \\
& $M \times A$ & 4 & 0.9760 & 1.5001 & 1.7268 & 4.3725 & $40.6897^{* *}$ & 4.4970 \\
二次誤差 & $e_{2}$ & 6 & $0.4990^{*}$ & $2.0354^{* *}$ & $5.7238^{* *}$ & $1.2088^{* *}$ & $8.9681^{* *}$ & $12.6224^{* *}$ \\
狭範囲(回帰) & $B_{l}$ & 1 & $* *$ & $* *$ & $* *$ & $* *$ & $* *$ & $* *$ \\
狭範囲(残差) & $B_{r}$ & 3 & 0.0989 & 0.0715 & $10.1241^{* *}$ & $6.4072^{* *}$ & $4.2763^{* *}$ & $18.7513^{* *}$ \\
& $M \times B_{l}$ & 2 & 0.0771 & 0.0488 & 0.0112 & 1.4062 & 2.1589 & $29.3349^{* *}$ \\
& $M \times B_{r}$ & 6 & 0.2805 & 0.2094 & 0.2811 & 0.8165 & 1.2298 & 3.3642 \\
& $A \times B_{l}$ & 2 & 0.1471 & 0.0702 & 0.7902 & 4.7007 & $10.2318^{* *}$ & $7.6222^{*}$ \\
& $A \times B_{r}$ & 6 & 0.1962 & 0.1281 & $1.7102^{* *}$ & $1.1023^{*}$ & 1.9810 & 1.5907 \\
& $M \times A \times B$ & 16 & 0.1503 & 0.1468 & 0.3763 & $0.7926^{*}$ & $4.1281^{* *}$ & 3.5669 \\
三次誤差 & $e_{3}$ & 36 & 0.2076 & $0.2831^{* *}$ & $0.3712^{* *}$ & $0.3798^{* *}$ & $1.1731^{* *}$ & $1.8858^{* *}$ \\
四次誤差 & $e_{4}$ & 90 & 0.1268 & 0.1064 & 0.1360 & 0.1342 & 0.1868 & 0.2154 \\
\hline
\end{tabular}

* 危険率 5\%で有意差のあることを示す

** 危険率 $1 \%$ で有意差のあることを示卞 
表 3 直線目盛の精度

(単位： $\mu \mathrm{m}$, 信頼率：99\%)

\begin{tabular}{|c|c|c|c|c|c|c|}
\hline \multirow{3}{*}{$\begin{array}{r}\text { 種 類 } \\
\text { 目量 }_{(\mu \mathrm{m})}\end{array}$} & \multirow{3}{*}{$\frac{\mid \text { 慓準尺 }}{100}$} & \multirow{2}{*}{ スケール } & \multicolumn{2}{|c|}{ コード板 } & \multicolumn{2}{|c|}{ スリット } \\
\hline & & & I & II & $\mathrm{I}$ & II \\
\hline & & 38 & 60 & 300 & 240 & 240 \\
\hline 広範用精宽 & 0.5 & 1.8 & 3.0 & 4.4 & 19.0 & 28.3 \\
\hline 狭範囲精宽 & 1.0 & 0.9 & 3.5 & 3.5 & 9.7 & 18.0 \\
\hline 繰返し測定の精麻 & 0.7 & 0.6 & 0.7 & 0.7 & 0.8 & 0.9 \\
\hline 最大寸法誤痓 & 1.3 & 2.8 & 2.5 & 4.1 & 5.9 & 5.7 \\
\hline
\end{tabular}

このようにして実際に得られた数值から精度評価を行

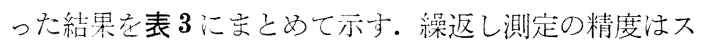
ケール, ニード板ぶ標準尺の場合と同程度の $0.7 \mu \mathrm{m}$ 以 下であり，スリット苍含的をも $1.0 \mu \mathrm{m}$ 以下といずれの 目盛の埸合にも十字線との合致の精度沈高いと言光る.

スアールの場合, 刻線方法が標準尺と同様であるため 狭範囲誤差注小さいが，広範囲になると若干大きな誤差 をもつ.乙かし，その大きさは $1.8 \mu \mathrm{m}$ と 1 目の $5 \%$ 以 下なので使用上の問題はない。

ニード板については, 1 目 $60 \mu \mathrm{m}$ のものも $300 \mu \mathrm{m}$ の ものもほぼ同様の性能を示している。 $B_{r}, A \times B_{r}$ などが 有意となっているぶ, 広範囲, 狭範囲ともに精度は約 3 $\mu \mathrm{m}$ であり, 1 目盛の $5 \%$ 以下の誤差におさまっている。 スリットの場合は, I, II ともに要因 $A, B_{r}, A \times B_{l}$ な どが有意となっているために，広範囲，狭範囲ともスケ ールやコード板に比べて精度が劣る.特にリン青銅製の 場合に注 $10 \%$ 前後の誤差となるので実用上の支障が若 干あると思わ秃る. 事実, この試料に対する公差は累積 誤差も含めて $10 \mu \mathrm{m}$ となっているので表 3 の值はこ机 を大幅化超光ている.

目盛の精度表示の方法として，JIS B 7541 (1973)「標 準尺」の項には,「任意の 2 線間の寸法誤差の絶対值で 表示する」と記されているが，この方法で 3 個の試料を 通じての最大寸法誤差を求めると，表 3 に同時に示した 值となる．種々の要因効果が無視できる標準尺及びスケ 一ルの場合には, 単純な測定のばらつきより寸法誤差の 最大值の方が大きくなるが、コード板やスリットの交互 作用を無視して寸法誤差の久で評価すると，誤差の過小 評価になってしまうことが上記の結果から明らかとなっ た.

\section{2 円弧目盛の場合}

円弧目盛についてはコード板のみであったので, 最小 目盛を示すパターンのかどを投影機で拡大して，スクリ ーン上の十字線と合致させる方法をとった. 円弧の両端
表 4 曲率半径の推定値の比較

\begin{tabular}{c|c|c|c}
\hline 試料反復 & $\begin{array}{c}\text { 三点法 } \\
(\mathrm{mm})\end{array}$ & $\begin{array}{c}\text { 最小二乗法 } \\
(\mathrm{mm})\end{array}$ \\
\hline 1 & 1 & 212.03 & $211.87 \pm 0.12$ \\
& 2 & 211.75 & $211.83 \pm 0.13$ \\
\hline 2 & 1 & 211.99 & $211.91 \pm 0.12$ \\
& 2 & 211.85 & $211.92 \pm 0.10$ \\
\hline 3 & 1 & 211.77 & $211.76 \pm 0.10$ \\
& 2 & 212.09 & $211.83 \pm 0.15$ \\
\hline
\end{tabular}

と中央の 3 品方ら円の中心学決定した場合と，2.2 節で 述べたように全測定点を用いて最小二乗法により推定し た場合の曲苜半径の比較を表 4 亿示す。後者の場合の方 が明ら品にばらつきが小さく， $0.06 \%$ 程度の推定精度 （信頼率 $99 \%$ ）が得ら秃ている. 目盛の精度解析法個々 の角度につき，直線目盛の場合之同様な方法で行った。 その結果, 三次誤差（標集偏差で $0.1^{\prime}$ ) に比べて二次誤 差が有意となっているのみで, 他の要因については有意 差が認內ら机なかった。そこで, $\hat{\sigma}_{e_{2}}^{2}$ から目盛の精度を評 価す机ば， $\pm 0.3^{\prime}$ が得られ 1 目盛の約 $5 \%$ に相当する. この程度の誤差は使用上無視できるので, このコード板 の精度注高いと言える。

\section{4. むす び}

はかり用の各種の目盛について実験計画法に基づいた 実験と解析から精度評価を行い, 次の結論を得た。

（1）直線目盛についてはレーザ干涉測長機を用いた 測定装置を試作して，1 $\mu \mathrm{m}$ 以下の誤差で測定でき ることを確かめた．スケール及びコード板の場合に は広範囲, 狭範囲ともに精度的に十分なものが得ら れているが，スリットの場合には 1 目盛に対して $10 \%$ 前後の誤差が生じるので目盛の読取りにおい て実用上支障があると思わ机る。

（2）円弧のコード板の場合には, 最小二乗法による円 弧の中心の推定方法を応用することにより，1目盛 の $5 \%$ 以下の誤差で製作されていることを確かめ た.

終わりに, 本研究に際して多大のご協力をいただいた 本学会はかりの精度調查分科会 (主查: 山本健太郎明治 大学工学部教授）の委員各位に感謝の意を表す.

\section{参考文 献}

1) K. Iizuka, H. Imai: Form Measurement of Smalk Spherical Surfaces by means of the Method of Least Squares, Bull. JSPE, 4, 1, (1970) 1. 


\section{軌道面に圧痕を生じた玉軸受の寿命についで}

長岡一

\section{1. 緒言}

静止している玉軸受が，大きな負荷を受けて玉による 圧痕を軌道面に生じた場合，この負荷の大きさと軸受の 基本静定格荷重とを比較して, 負荷が定格荷重より大き ければ，負荷を受けた軸受は安定した運転が期待できな いとされている。

ここでは，この圧痕を生じた玉軸受の寿命について， 軌道面澄生する応力の状態から考察を加えた。

従来, 応力（残留応力を含的て）の立場から軸受寿命 を論じた文献は数多いが, 軌道面の部分的な圧痕部分に 生ずる応力空とりあげたものは見当たらない。

\section{2. 実例}

まず実験結果として,静止状態で基本静定格荷重 $\left(C_{0}=\right.$ $2300 \mathrm{~kg}$ ）を超える荷重などを加えて 軌道面に 压痕を生 じた王軸受 6206 を運転して, 静止荷重と内輪の寿命と の関倸它求めた結果注 1 で, 各試料間に有意差注認内 られない1. なお, この場合の運転中の最小油膜厚さ注, 純ころがり運動が行われるとして $0.3 \mu \mathrm{m}$ と計算され る2).この值法軌道面と玉の粗さの和より大きい值であ る.

\section{3. 応力の状態}

静止荷重を加えることによって生じた内輸軌道面圧痕 部の内部の残留応力注, せ九断降伏応力 $\tau_{k} に \tau_{k}=1 / 6 H_{V}$ $\left(H_{V} \text { はビッカースかたさ }\right)^{3)}$ の関係を用いて $\tau_{k}=120 \mathrm{~kg}$ / $\mathrm{mm}^{2}$ とすると, ころがり方向に $\left(\sigma_{x}\right)_{r}=2\left(120-\tau_{45}\right)^{4}$ $\left(\tau_{45}\right.$ 注静的せえ断応力. $\left(\sigma_{x}\right)_{r}$ 注 $120 \mathrm{~kg} / \mathrm{mm}^{2} \leqq \tau_{45} \leqq 190$ $\mathrm{kg} / \mathrm{mm}^{2}$ で成り立つと仮定）となる. 残留応力り計算值

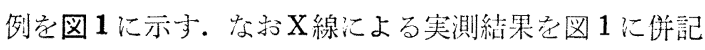
したが，軌道表面付近にかなり大きい王縮の残留応力が 認的られるほ和注ほほ計算值化近い。

各圧痕部分の表面下に運転中に働くせ九断応力 $\left(\tau_{45}\right)_{r}$ は，運転荷重のみによって生ずるせ九断态力と，ころが り方向の残留応力の $1 / 2$ の和であり, 内輸軌道面を真円

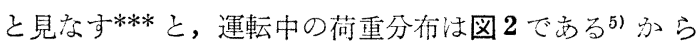
$\left(\tau_{45}\right)_{r}$ の範囲はたとえば図 3 のとおりである。ただし表

* 原稿受付 昭和 51 年 10 月 7 日.

** 正会 員 光洋精工(株) (大阪市南区綬谷西之町 2)
面付近に実測された圧縮応力はこの図では無視した。

表 1 寿命試験結果

試料：6206（運転すきま9～14 $\mu \mathrm{m}$ )

試験条件 荷重：外輪を両側から $700 \mathrm{~kg}$ でおさえる. 回転 数: 内輪 $1770 \mathrm{rpm}$. 潤滑: \#180 タービン油榈下.

(単位: h)

\begin{tabular}{|c|c|c|c|c|c|}
\hline 静止荷重 & $\begin{array}{l}1000 \mathrm{~kg} \\
0.4 C_{0} \\
\text { 相当 }\end{array}$ & $\begin{array}{l}2000 \mathrm{~kg} \\
0.9 C_{0} \\
\text { 相当 }\end{array}$ & $\begin{array}{l}4000 \mathrm{~kg} \\
1.7 C_{0} \\
\text { 相当 }\end{array}$ & $\begin{array}{l}5000 \mathrm{~kg} \\
2.2 C_{0} \\
\text { 相当 }\end{array}$ & 0 \\
\hline & 61.7 & 86.7 & 40.6 & $15.0 \dagger$ & 35.8 \\
\hline 内輪寿命 & 61.8 & 42.4 & 13.8 & 60.7 & 82.0 \\
\hline の & 50.1 & 13.8 & 28.0 & 66.5 & 96.0 \\
\hline \multirow{2}{*}{ 实 測 值 } & 53.6 & 25.8 & 56.3 & 24.7 & 99.8 \\
\hline & 93.7 & 85.0 & 174.1 & 103.2 & 113.8 \\
\hline 1の & 64.2 & 50.7 & 62.6 & $\begin{array}{c}54.0 \\
\dagger を \text { 除くと } \\
63.8\end{array}$ & 85.5 \\
\hline
\end{tabular}

†圧痕部にフレーキングが発生した。これ以外はすべてフレ ーキングは圧痕部㒇関係の位置に発生した。

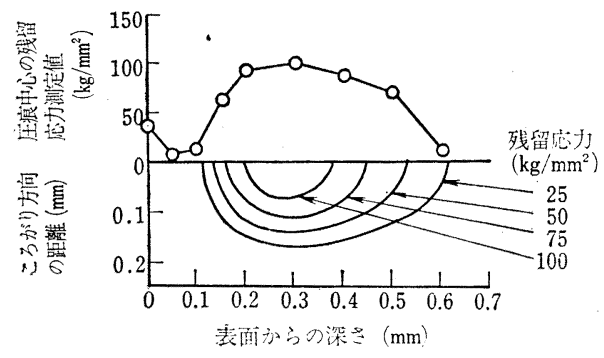

（a）静止荷重 $4000 \mathrm{~kg}$ の最大压窟部での值

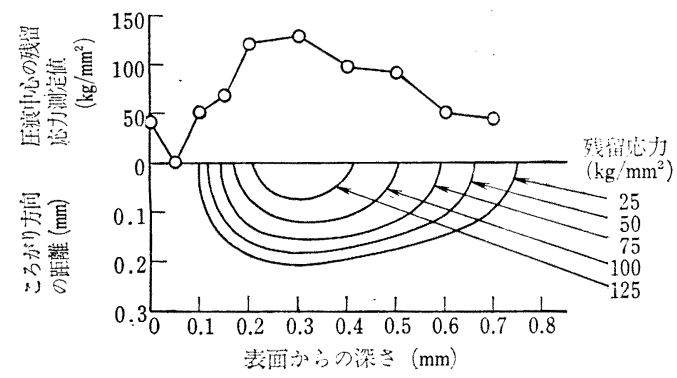

（b）静止荷重 $5000 \mathrm{~kg}$ の最大压瘦部での值

图 1 静止荷重注よって生じた圧痕部付沂の残留応力

*** 各压痕の深さが円周方向にゆるやかに変化しているこ と, および压痕が玉のピッチに生じており，玉王同時化 各圧痕位置に達するものとすれば負荷状態は常に一定ゆ 衣, 荷重分布に関しては内輪滇円と見なせる. 


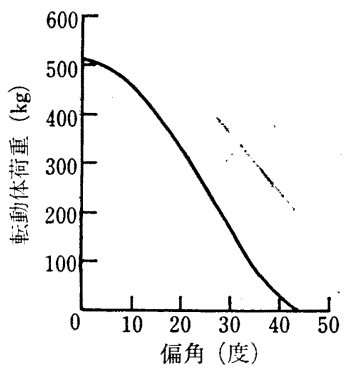

偏角 0 度を中心として対称形に分布， および 180 度対称に同じ分布がある

図 2 荷重 分布

これらの曲線の最大值と最小值の各絶体值がほぼ等量 と考え, その平均值をもって最大せえ断応力值とし, そ 机らの平均深さをもって, この応力の働く深さと考え る.ただし，負荷の大きさにもよるが残留応力は運転に よって変化するといわれ, 初期の残留応力に無関係に一 定量変化するとした ${ }^{6)}$ 場合, 図 3 の各曲線は, ほぼ $x$ 軸 方向に平行移動するのみで上記平均注变わらないといえ る.

一方，ころがり方向に平行なせん断応力 $\tau_{x y}$ は残留応 力成分はなく一定の值をとる. 従ってこの応力の最大值 と上記平均值とを比較して, 大きい方の応力を対象応力 とし, その応力の㗢く深さを対象応力の深さとしてとり 上げることにした。

\section{4. 寿 命 計 算}

応力と寿命との間に法次の関係がある7).

$$
\log \frac{1}{S} \propto l\left\{\int_{0}^{N}\left(a \tau_{0}{ }^{c} z_{0}^{1-h}\right)^{1 / e} \mathrm{~d} N\right\}^{e}
$$

ここに, $S$ は $N$ 回の繰返しに耐えられる確率, $l$ は軌道 面の長さ, $a$ 淁触棈円の長軸半径, $\tau_{0}$ は最大せ九断応 力, $z_{0}$ 注その応力の㗢く深さ, $c, h$ および $e$ は材料によ ってきまる指数である. 一方, $u$ を軌道が 1 回転すると きの忘力の繰返し数, $L$ 百万回転単位の寿命 (MR で 表す), $D_{i}$ 它内輪軌道径, $\phi$ 它偏角とすれば $\mathrm{d} N=\mathrm{d} u L \propto$ $D_{i} / 2 \cdot \mathrm{d} \varphi$ より, $A$ を定数, $\phi_{0} \sim-\psi_{0}$ を負荷圈の範囲と して, 式(1) は次のように表される。

$$
\log \frac{1}{S}=A \int_{0}^{2 \pi}\left\{\int_{-\psi_{0}}^{\psi_{0}}\left(a \tau_{0}{ }^{c} z_{0}{ }^{1-h}\right)^{1 / e} L \frac{D_{i}}{2} \mathrm{~d} \psi\right\}^{e} \frac{D_{i}}{2} \mathrm{~d} \psi
$$

圧痕の有無にかかわらず, 潤滑の条件, 接線力の条件 が同一で，この式 (2)が成立するとすれば，圧痕の有り， および無しの場合の内輪の寿命をそれぞれ $L_{P}$ および $L$ とし， $S_{P}=S\left(\right.$ 添字 $P$ 注圧痕有りを表す)とおいて ${ }^{8)}$

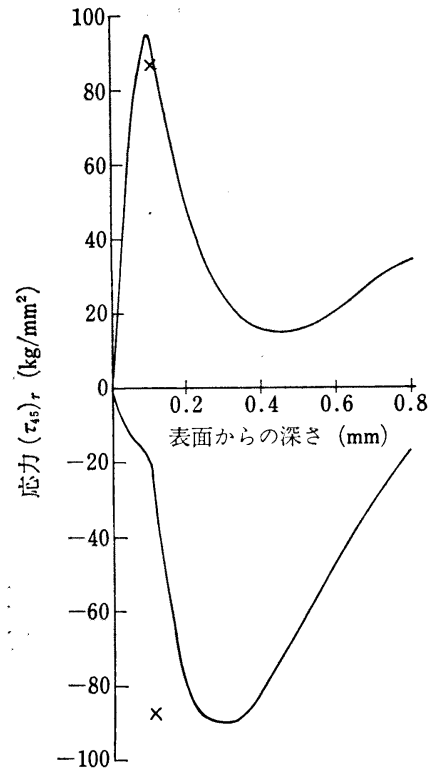

（a）静止荷重 $5000 \mathrm{~kg}$ の最大圧痕中心部において 運転時の転動体荷重 $523 \mathrm{~kg}$ のとき

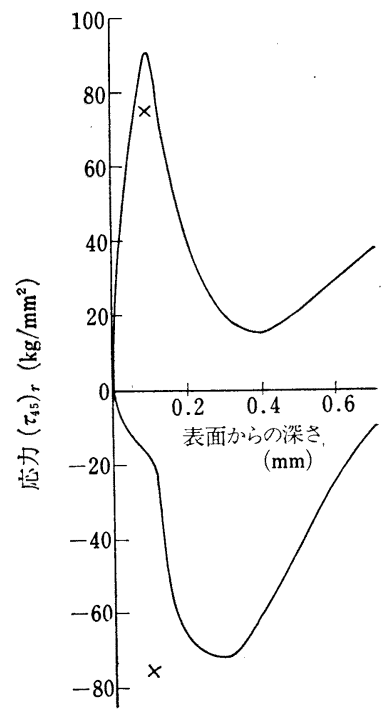

（b）静止荷重 $4000 \mathrm{~kg}$ の最大圧痕中心部において 運転時の転動体荷重 $343 \mathrm{~kg}$ のとき ×印: $\tau_{x y}$ の最大值

图 3 静止荷重によって生じた圧痕部を玉が通過 するときの応力

$$
L_{P}=\left(\frac{2 \pi\left\{\int_{-\psi_{0}}^{\psi_{0}}\left(a \tau_{0} c z_{0}^{1-h}\right)^{1 / e} \mathrm{~d} \psi\right\}^{e}}{\int_{0}^{2 \pi}\left\{\int_{-\psi_{0}}^{\psi_{0}}\left(a_{P} \tau_{0 P} c z_{0 P}{ }^{1-h}\right)^{1 / e} \mathrm{~d} \phi\right\}^{e} \mathrm{~d} \phi}\right)^{1 / e} L
$$

さらに, 内輪の圧痕部 $\left(\tau_{x} y\right.$ より大きな応力が生ずる 
表 2 表 1 の条件における寿命計算結果

\begin{tabular}{|c|c|c|c|c|}
\hline 静 止 荷 重 & $\begin{array}{l}4000 \mathrm{~kg} \\
1.7 C_{0} \\
\text { 相当 }\end{array}$ & $\begin{array}{l}4300 \mathrm{~kg} \\
1.9 C_{0} \\
\text { 相当 } \\
\end{array}$ & $\begin{array}{l}4700 \mathrm{~kg} \\
2.0 C_{0} \\
\text { 相当 }\end{array}$ & $\begin{array}{l}5000 \mathrm{~kg} \\
22 C_{0} \\
\text { 相当 } \\
\end{array}$ \\
\hline $\begin{array}{l}\text { 质痕のない内輪に対する寿 } \\
\text { 命比率 }(\%)\end{array}$ & 100.00 & 100.00 & 99.98 & 99.97 \\
\hline 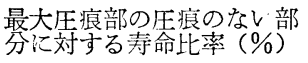 & 99.7 & 98.5 & 94.2 & 89.9 \\
\hline
\end{tabular}

表 3 純ラジアル荷重 $350 \mathrm{~kg}$ が働くときの寿命計算結果

\begin{tabular}{|c|c|c|c|c|}
\hline 静 止 荷 重 & $\begin{array}{l}3300 \mathrm{~kg} \\
1.4 C_{0} \\
\text { 相当 }\end{array}$ & $\begin{array}{l}4000 \mathrm{~kg} \\
1.7 C_{0} \\
\text { 相当 }\end{array}$ & $\begin{array}{l}4500 \mathrm{~kg} \\
2.0 C_{0} \\
\text { 相当 }\end{array}$ & $\begin{array}{l}5000 \mathrm{~kg} \\
2.2 C_{0} \\
\text { 相当 }\end{array}$ \\
\hline $\begin{array}{l}\text { 压痕のない内輪に対する寿 } \\
\text { 命比率 }(\%)\end{array}$ & 100.00 & 99.88 & 99.66 & 99.39 \\
\hline $\begin{array}{l}\text { 最大压痕部の压痕のない部 } \\
\text { 分に対する寿命比率 }(\%) \text { ) }\end{array}$ & 88.0 & 49.3 & 32.0 & 19.4 \\
\hline
\end{tabular}

は他の型番のときも同様に計算できるが，一般に 運転荷重が低いときは, 圧痕の影響は多少大きく 現れ，許しうる圧痕の大きさ，すなわち許しうる 静止荷重が小さくなる.たとえば 6206 で純ラジ アル 荷重 $350 \mathrm{~kg}$ (最大転動体荷重 $183.8 \mathrm{~kg}$ ) が働 くときには表 3 のと打り $3300 \mathrm{~kg}$ の静止荷重で生 じた圧痕部の寿命が压痕のない部分の寿命よりも $10 \%$ 短くなると計算される.

なお，表 1 で有意差がないとはい圧痕のない 軸受の寿命の平均値が長いということは, 低荷重 での摩擦トルク值が低いこと1からも上述のほか 衝撃, 油膜厚さ(圧痕の肩部の), 拉よびいくつか の玉が压痕部に落ち込もとき他のいくつかの玉に 範囲）の寿命，およびそれと等円周長さの圧痕のない部 分の寿命をそれぞれ $L_{p}$, および $L^{\prime}$ とすれば（添字 $p$ 沫 圧痕部を表す）等円周長さを $2 B=2 \beta \times D_{i} / 2$ として，

$$
L_{p}=\left(\frac{4 B\left\{\int_{-\psi_{0}}^{\psi_{0}}\left(a^{\prime} \tau_{0}{ }^{\prime} c z_{0}{ }^{1-h}\right)^{1 / e} \mathrm{~d} \varphi\right\}^{e}}{D_{i} \int_{0}^{2 \beta}\left\{\int_{-\psi_{0}}^{\psi_{0}}\left(a_{p} \tau_{0 p}{ }^{c} z_{0 p}{ }^{1-h}\right)^{1 / e} \mathrm{~d} \phi\right\}^{e} \mathrm{~d} \psi}\right)^{1 / e} L^{\prime}
$$

となる。

\section{5. 計 算 結 果}

$c=10^{1 / 3}, h=2^{1 / 3}, e=10 / 9$ として ${ }^{9)}$, 各压痕を生じた 内輪の寿命の圧痕のない寿命に対する比率，および各最 大圧痕部の圧痕のない部分に対する寿命比率汢表 2 のと おりである，ただし压痕部に㧍いても Hertz式が成り立 つものとして計算した。

計算の結果から, 取付後静止している間に, 基本静定 格荷重の 2.2 倍程度までの荷重を加えられて, 内輪軌道 面に深さ $0.0046 \mathrm{~mm}$ 程度の圧痕を生じた軸受を運転し ても, 振動や大きな集中応力を発生しない限り注軸受の 寿命注とえど短くならない。これは交献 1)で得られ た結果にほぼ一致する。

ある大きさを超える压痕部分の寿命は，圧痕のない部 分の寿命より短くなるが，その幅が小さいために全体の 寿命に注注とえど影響を与えない。ただし，压痕部のみ の寿命を考えた場合には $4700 \mathrm{~kg}$ ( $C_{0}$ の 2 倍) の荷重を 加えて生じた圧痕部の寿命は圧痕のない同長幅部分の寿 命より $5 \%$ 程度短くなる. 従って, この場合に軸受に加 える静荷重は $C_{0}$ の 2 倍程度までが, 寿命の面から見る 限り許しうる荷重と考えられる. 表 1 でも $1.7 C_{0}$ 相当ま では圧痕部に破損が起こっていない.

なお，一般に運転荷重がこの例と異なる場合，あるい
起こる荷重の増加の影響が考えられる.Chiu らは軌道表 面に微小なきずが在るときその肩部に生ずる圧力を求的 ている(10)が, 王の曲率半径が压痕の曲率半径より大きい と仮定して 同様に計算すると $5000 \mathrm{~kg}\left(C_{0}\right.$ の 2.2 倍) の 静止荷重安加えて生じた最大压痕の肩部の圧力 $p_{\text {max }}$ 沫 圧痕部以外での圧力を $p_{0}$ として約 $1.7 p_{0}$ と求められる. 德島大学藤原晴夫先生に種々御教示を頂いた。記して 謝意を表する。

\section{文献}

1）前川良雄, 長岡一三，阪井正光：軌道面に圧痕または銷 を生じた軸受トルクおよび寿命について，自動車技術， 15, 6 (1961) 250 .

2) 例えば, H.S. Cheng: A Numerical Solution of the Elastohydrodynamic Film Thickness in an Elliptical Contact, Trans. ASME, Ser. F, 92, 1, (1970) 155.

3) D. Tabor: The Hardness of Metals, Oxford, (1951) 105.

4) J. E. Merwin \& K. L. Johnson: An Analysis of Plastic Deformation in Rolling Contact, Proc. Inst. Mech. Engrs., 177, (1963) 676.

5）長岡一三：はめあい等によって転走面にうねりを生じた 玉軸受の荷重分布㧍よび寿 命について, 閡滑, 19, 8 (1974) 594

6）喜慰斗政夫：ころがり軸受工学（18），機械の研究， 23, 4 (1971) 640.

7) G. Lundberg \& A. Palmgren: Dynamic Capacity of Rolling Bearings, Generalstabens Litografiska Anstalts Förlag, Stockholm, (1947) 12.

8) T.A.Harris: Rolling Bearing Analysis, J. Wiley, N. Y., (1966) 353.

9) 交献 6) の p. 19.

10) Y.P. Chiu \& J. Y. Liu: An Analytical Study of the Stress Concentration around a Furrow Shaped Surface in Rolling Contact, Trans. ASME, Ser. F, 92, 2, (1970) 258. 